\section{Lettuce Response to Phosphorus Fertilization in High Phosphorus soils}

\author{
P.R. Johnstone, T.K. Hartz, M.D. Cahn, ${ }^{1}$ and M.R. Johnstone \\ Department of Plant Sciences, University of California, Davis, CA 95616
}

Additional index words. Lactuca sativa, bicarbonate-extractable P, bioavailable P, Olsen P, soil temperature

\begin{abstract}
Decades of heavy phosphorus (P) fertilization of vegetable crops in the Salinas Valley of California has increased soil test P (STP) levels, with bicarbonate-extractable $P$ $\left(P_{\text {bc }}\right)$ values $>50 \mathrm{mg} \cdot \mathrm{kg}^{-1}$ now common. To evaluate the response of lettuce (Lactuca sativa L.) to $P$ fertilization in fields with elevated STP levels, 12 trials were conducted in commercial fields during 2002-03. Initial $P_{b c}$ at the trial sites varied from 53 to $171 \mathrm{mg} \cdot \mathrm{kg}^{-1}$. In each trial, four replicate plots receiving the growers' $P$ application were compared with paired plots in which no $P$ was applied. Leaf $P$ was monitored at midseason and at harvest. At harvest, mean whole and marketable plant mass and percent of marketable plants were recorded. A significant increase in lettuce yield with $P$ fertilization was achieved at only one trial site, a spring planting with $54 \mathrm{mg} \cdot \mathrm{kg}^{-1} \mathrm{P}_{\mathrm{bc}}$; at all other sites, including three with $P_{b c}<60 \mathrm{mg} \cdot \mathrm{kg}^{-1}, P$ application resulted in no significant yield increase. Phosphorus application resulted in only a marginal increase in plant $P$ uptake; in the nonresponsive fields leaf $P$ concentration of nonfertilized plots was in excess of established sufficiency levels. In a laboratory study, the correlation of $P_{b c}$ to bioavailable $P\left(P_{b a}\right)$ was evaluated using 30 representative Salinas Valley soils; $P_{b c}$ varied among these soils from 15 to 177 $\mathrm{mg} \cdot \mathrm{kg}^{-1} \cdot \mathrm{P}_{\mathrm{ba}}$ was estimated by $P$ adsorption on an anion resin membrane during a 16 hour incubation. The effect of temperature on $P$ bioavailability in six of these soils was estimated by conducting the $P_{b a}$ incubation at 5,15 , and $25^{\circ} \mathrm{C}$. $P_{b a}$ was highly correlated with $P_{b c}(r=0.89)$, and increased about $40 \%$ across soils with each $10{ }^{\circ} \mathrm{C}$ increase in soil temperature. Therefore, $P_{b c}$ was determined to be an accurate reflection of bioavailable $P$ in these soils, although the addition of a temperature correction factor in setting threshold values is desirable.
\end{abstract}

Decades of heavy phosphorus fertilizer application to vegetable fields in the Salinas Valley ofCalifornia has substantially increased soil test P (STP) concentration. In a recent survey of commercial vegetable fields in the valley, $\mathrm{STP}$ (bicarbonate-extractable, $\mathrm{P}_{\mathrm{bc}}$, Olsen and Sommers, 1982) averaged $67 \mathrm{mg} \cdot \mathrm{kg}^{-1}$, with nearly half of the soils $>80 \mathrm{mg} \cdot \mathrm{kg}^{-1}$ (T.K. Hartz, unpublished data). While excessive $\mathrm{P}$ fertilization generally does not cause serious agronomic problems, it can be a significant contributor to P pollution of surface waterways (Pote et al., 1996). Segments of the Salinas and Pajaro River systems have been placed on the Environmental Protection Agency 303(d) list for excessive nutrient concentration. STP has been shown to be positively correlated with $\mathrm{P}$ concentration in field runoff from irrigation or rainfall (Johnstone and Hartz, 2004; McDowell and Sharpley, 2001; Pote et al., 1996; Sharpley, 1995). The negative effect of high soluble $P$ levels on the eutrophication of water bodies has been well documented (Pote et al., 1996; Sims, 1998).

Despite elevated STP many Salinas Valley growers continue to apply $\mathrm{P}$ to ensure peak production. For a number of agronomic crops, $\mathrm{P}_{\mathrm{bc}}>15-30 \mathrm{mg} \cdot \mathrm{kg}^{-1}$ is generally interpreted as

Received for publication 18 Feb. 2005. Accepted for publication 25 Mar. 2005. We gratefully acknowledge the support of the California Department of Food and Agriculture Fertilizer Research and Education Program (FREP).

${ }^{1}$ University of California Cooperative Extension, Monterey County. sufficient for maximum yield (Ludwick, 2002; Reisenauer, 1983). There is evidence that lettuce has higher soil P sufficiency requirements than other crops (Fox, 1981, Greenwood et al., 1980; Kumar et al., 1992; McPharlin et al., 1996; Prasad et al., 1988). Fox (1981) reported that lettuce required a higher soil solution $P$ concentration for maximum growth than other crops such as cabbage (Brassica oleracea L.), corn (Zea mays L.), or tomato (Lycospersicon esculentum Mill.). On low STP soils, Greenwood et al. (1980) suggested that the optimum rate of $\mathrm{P}$ fertilizer for lettuce was about $230 \mathrm{~kg} \cdot \mathrm{ha}^{-1}$, while many other vegetable crops required $<50 \mathrm{~kg} \cdot \mathrm{ha}^{-1}$. Varying STP thresholds have been reported for lettuce (Diaz et al., 1988; Ludwick, 2002; McPharlin et al., 1996; Nagata et al., 1992; Prasad et al., 1988; Sanchez and El-Hout, 1995). Ludwick (2002) suggested that $P_{b c}>35 \mathrm{mg} \cdot \mathrm{kg}^{-1}$ was sufficient for lettuce production. Prasad et al. (1998) recommended a threshold $\mathrm{P}_{\mathrm{bc}}$ of 46 $\mathrm{mg} \cdot \mathrm{kg}^{-1}$ for maximum yield, although they suggested lettuce grown in spring may require a higher value than summer. McPharlin et al. (1996) suggested that fertilization sufficient to increase $\mathrm{P}_{\mathrm{bc}}$ to $80 \mathrm{mg} \cdot \mathrm{kg}^{-1}$ was required to guarantee at least $95 \%$ of maximum lettuce yield. This research was conducted on a newly cleared soil of low natural P fertility; the P dynamics of such soil may be quite different from soil that has received intensive $P$ application over decades.

Some research suggests that traditional chemical extraction procedures (such as $\mathrm{P}_{\mathrm{bc}}$ ) may not reliably predict plant-available $\mathrm{P}$ in the soil (Sims et al., 2000); certainly there is a general reluctance by vegetable growers to base $\mathrm{P}$ fertilizer decisions solely on the results of such methods, particularly while $\mathrm{P}$ fertilizer costs are not a major expense for such high value crops. Chemical extractants typically measure static $\mathrm{P}$ pools and may also mobilize $\mathrm{P}$ forms that are not plant-available (Cooperband and Logan, 1994). Techniques that measure bioavailable $\mathrm{P}\left(\mathrm{P}_{\mathrm{ba}}\right)$ may be more closely correlated with crop response (Cooperband and Logan, 1994; Magdoff et al., 1999; Menon et al., 1990). Unfortunately, there has been no systematic comparison of $\mathrm{P}_{\mathrm{bc}}$ (the standard agronomic soil test) with $\mathrm{P}_{\mathrm{ba}}$ techniques that focused on soils characteristic of coastal California (neutral to alkaline $\mathrm{pH}$, enriched primarily by mineral fertilizers).

This project was undertaken to re-examine P management recommendations for lettuce production in the Salinas Valley. Additionally, the relationship between $\mathrm{P}_{b c}$ and $\mathrm{P}_{\mathrm{ba}}$ was evaluated for a range of soil from long-term vegetable rotations.

\section{Materials and Methods}

Twelve field trials were conducted in commercial fields in the Salinas Valley in 2002 and 2003, evaluating whether $P$ fertilization affected lettuce production in fields with moderate to high $\mathrm{P}_{\mathrm{bc}}\left(>50 \mathrm{mg} \cdot \mathrm{kg}^{-1}\right)$. Representative soil samples were collected in each field from the top $15 \mathrm{~cm}$ of soil. Soil was air-dried and sieved to pass a $2 \mathrm{~mm}$ screen. Particle size analysis was performed by the method of Gee and Bauder (1982) and $\mathrm{P}_{\mathrm{bc}}$ was determined by the method of Olsen and Sommers (1982). Soil $\mathrm{pH}$ was measured on saturated paste extracts; all soils had neutral to alkaline $\mathrm{pH}$ (7.0 to 7.8). The fields chosen had STP values that varied from 53 to $171 \mathrm{mg} \cdot \mathrm{kg}^{-1}$, with a range of soil textures (Table 1). Planting dates varied from late January through late July, with harvests ocurring from early May through late September.

The experimental design in all fields was a randomized complete block comprised of two treatments (plus $\mathrm{P}$ and no P) with four replications. Individual plots were four beds, 1 $\mathrm{m}$ wide $\times 60 \mathrm{~m}$ long. All data were collected in the middle $30 \mathrm{~m}$ of each plot, from the middle two beds. The cooperating growers determined the quantity of $\mathrm{P}$ applied to their fields. In ten fields the grower applied preplant $\mathrm{P}$, either broadcast or banded during bed formation. Four control plots per field were established in which this Papplication was skipped. In the remaining two fields (4 and 10) the grower did not apply preplant $P$ fertilizer; four plots were established in each of these fields in which preplant $\mathrm{P}$ was broadcast at $64 \mathrm{~kg} \cdot \mathrm{ha}^{-1}$. No supplemental $\mathrm{P}$ was applied following crop emergence in any field. All fields were sprinkler irrigated, and standard commercial production practices were followed.

To document the effect of $\mathrm{P}$ fertilization on early growth the percent of plant canopy cover before cupping was quantified by digital infrared photography (Dycam Inc., Woodland 


\begin{tabular}{|c|c|c|c|c|c|c|c|}
\hline Field & Location & $\begin{array}{c}\text { Bicarbonate } \\
\mathrm{P}^{\mathrm{z}} \\
\left(\mathrm{mg} \cdot \mathrm{kg}^{-1}\right)\end{array}$ & $\begin{array}{c}\mathrm{P} \\
\text { application } \\
\text { rate } \\
\left(\mathrm{kg} \cdot \mathrm{ha}^{-1}\right)\end{array}$ & $\begin{array}{l}\text { Lettuce } \\
\text { type }\end{array}$ & $\begin{array}{l}\text { Soil } \\
\text { texture }\end{array}$ & $\begin{array}{l}\text { Planting } \\
\text { date }^{\mathrm{y}}\end{array}$ & $\begin{array}{c}\text { Harvest } \\
\text { date }\end{array}$ \\
\hline 1 & Salinas & 54 & 29 & Iceberg & Clay & 3 Apr. 2002 & 20 June 2002 \\
\hline 3 & Chualar & 72 & 21 & Iceberg & Clay loam & 12 June 2002 & 17 Aug. 2002 \\
\hline 4 & Chualar & 171 & 64 & Iceberg & Sandy loam & 15 July 2002 & 27 Sept. 2002 \\
\hline 5 & King City & 57 & 39 & Iceberg & Silty clay loam & 27 Jan. 2003 & 5 May 2003 \\
\hline 8 & King City & 82 & 39 & Iceberg & Silty clay loam & 26 Feb. 2003 & 19 May 2003 \\
\hline 9 & Salinas & 81 & 30 & Iceberg & Loam & 20 May 2003 & 11 Aug. 2003 \\
\hline 10 & Soledad & 55 & 64 & Romaine & Loam & 11 May 2002 & 22 July 2002 \\
\hline 11 & Chualar & 78 & 36 & Romaine & Loam & 26 July 2002 & 27 Sept. 2002 \\
\hline 12 & Salinas & 98 & 26 & Romaine & Clay loam & 10 Feb. 2003 & 8 May 2003 \\
\hline
\end{tabular}

${ }^{2}$ Top $15 \mathrm{~cm}$ of soil.

${ }^{\mathrm{y}}$ Date of first irrigation to initiate germination.

Hills, Calif.); canopy referred to the percent of soil bed covered with photosynthetically active tissue. Two images were taken per plot. Whole leaf total $\mathrm{P}$ and midrib extractable $\mathrm{PO}_{4}-\mathrm{P}$ concentration were monitored at heading stage. At commercial maturity the total $P$ concentration of both the harvested head tissue and plant residue was determined. Tissue samples were oven-dried at $65^{\circ} \mathrm{C}$, then ground. Total $\mathrm{P}$ was determined by ICP-AES (Thermo Iris, Thermo Co., San Jose, Calif.) (Meyer and Keliher, 1992) following microwave digestion with nitric acid and hydrogen peroxide (Sah and Miller, 1992). Extractable $\mathrm{PO}_{4}-\mathrm{P}$ was determined by flow injection analysis following acetic acid digestion (Lachat Quik Chem 8000; Lachat Instruments, Milwaukee, Wis.) (Prokopy, 1995).

Immediately before commercial harvest, 30 to 40 randomly selected whole plants per plot were harvested and weighed. These whole plants were then trimmed according to market standards and marketable mass was recorded. In nine fields a count of total plants within each plot was taken; following the commercial harvest a count of unmarketable heads remaining was made and the percent of plants harvested was calculated. Statistical analysis was performed by field using the GLM-ANOVA procedure within SAS software.

A laboratory study was conducted to evaluate the relationship between $\mathrm{P}_{\mathrm{bc}}$ and bioavailable $\mathrm{P}\left(\mathrm{P}_{\mathrm{ba}}\right)$; the effect of soil temperature on bioavailable $\mathrm{P}$ was also determined. Soil $(0$ to $15 \mathrm{~cm}$ depth) from 30 fields in the Salinas and Pajaro Valleys was collected in the spring of 2002. Most fields were in long-term commercial vegetable rotations, with a mix of conventionally and organically managed sites. Soils were air-dried and sieved to pass a $2-\mathrm{mm}$ screen. Texture, $\mathrm{P}_{\mathrm{bc}}$ and $\mathrm{pH}$ were determined as previously described. Bioavailable $\mathrm{P}$ was characterized using a modification of the anion resin membrane technique of Cooperband and Logan (1994). Anion membrane disks (AG 1-X8; Bio-Rad Lab, Richmond, Calif.) with a reactive area of $130 \mathrm{~mm}^{2}$ were eluted twice in $0.5 \mathrm{M}$ sodium bicarbonate, and then rinsed with deionized water. Soil wetted to 2.5 times the gravimetric water content at field capacity was compressed on top of the membrane to ensure complete contact with the reactive surface. Samples were incubated at $20^{\circ} \mathrm{C}$ for
16 hours. The membranes were then rinsed with deionized water to remove adhering soil particles, and eluted in $40 \mathrm{~mL} 0.5 \mathrm{M} \mathrm{HCl}$ for 1 hour with agitation to detach adsorbed $\mathrm{P}$. The extract was analyzed for soluble $\mathrm{PO}_{4}-\mathrm{P}$ by flow injection (Lachat Quik Chem 8000; Lachat Instruments) (Franson, 1998). There were three replicate membrane incubations per field soil. The effect of temperature on $\mathrm{P}$ bioavailability was investigated in six of the soils. The membrane incubation procedure was repeated at 5,15 , and $25^{\circ} \mathrm{C}$. Incubations were replicated three times for each soil and temperature combination. Before all $\mathrm{P}_{\mathrm{b}}$ determinations, the soils were leached with $0.01 \mathrm{M} \mathrm{CaCl}_{2}$ solution to reduce soil $\mathrm{NO}_{3}-\mathrm{N}$ concentration below $5 \mathrm{mg} \cdot \mathrm{kg}^{-1}$, since $\mathrm{NO}_{3}-\mathrm{N}$ can suppress $\mathrm{P}$ adsorption (Cooperband and Logan, 1994).

Table 2. Effect of P fertilization on lettuce growth and marketable yield.

\begin{tabular}{|c|c|c|c|c|}
\hline Field & $\begin{array}{c}\mathrm{P} \\
\text { application } \\
\left(\mathrm{kg} \cdot \mathrm{ha}^{-1}\right)\end{array}$ & $\begin{array}{c}\text { Marketable } \\
\text { plants } \\
(\%)\end{array}$ & $\begin{array}{c}\text { Whole-plant } \\
\text { mass } \\
(\mathrm{kg})\end{array}$ & $\begin{array}{l}\text { Marketable } \\
\text { plant mass } \\
(\mathrm{kg})\end{array}$ \\
\hline \multicolumn{5}{|c|}{ Iceberg lettuce } \\
\hline \multirow[t]{2}{*}{1} & 0 & $81^{z}$ & $0.97^{2}$ & $0.67^{z}$ \\
\hline & 29 & 87 & 1.04 & 0.71 \\
\hline \multirow[t]{2}{*}{2} & 0 & 93 & 1.10 & 0.72 \\
\hline & 30 & 95 & 1.15 & 0.71 \\
\hline \multirow[t]{2}{*}{3} & 0 & 84 & 1.16 & 0.75 \\
\hline & 21 & 83 & 1.20 & 0.77 \\
\hline \multirow[t]{2}{*}{4} & 0 & 75 & 0.70 & 0.48 \\
\hline & 64 & 77 & 0.71 & 0.49 \\
\hline \multirow[t]{2}{*}{5} & 0 & 91 & 1.05 & 0.61 \\
\hline & 39 & 92 & 1.04 & 0.61 \\
\hline \multirow[t]{2}{*}{6} & 0 & 77 & 1.14 & 0.68 \\
\hline & 37 & 68 & 1.10 & 0.65 \\
\hline \multirow[t]{2}{*}{7} & 0 & 90 & 0.91 & 0.44 \\
\hline & 37 & 91 & 1.00 & 0.51 \\
\hline \multirow[t]{2}{*}{8} & 0 & 87 & 0.94 & 0.61 \\
\hline & 39 & 87 & 0.91 & 0.60 \\
\hline \multirow[t]{2}{*}{9} & 0 & 87 & 1.18 & 0.83 \\
\hline & 30 & 83 & 1.13 & 0.75 \\
\hline \multirow[t]{2}{*}{ Average } & No $P$ & 85 & 1.02 & 0.64 \\
\hline & Grower P & 85 & 1.03 & 0.64 \\
\hline \multicolumn{5}{|c|}{ Romaine lettuce } \\
\hline \multirow[t]{2}{*}{10} & 0 & & 0.70 & 0.48 \\
\hline & 64 & & 0.75 & 0.49 \\
\hline \multirow[t]{2}{*}{11} & 0 & & 0.55 & 0.41 \\
\hline & 36 & & 0.53 & 0.40 \\
\hline \multirow[t]{2}{*}{12} & 0 & & 1.05 & 0.65 \\
\hline & 26 & & 1.08 & 0.67 \\
\hline \multirow[t]{2}{*}{ Average } & No $P$ & & 0.77 & 0.51 \\
\hline & Grower P & & 0.79 & 0.52 \\
\hline
\end{tabular}

${ }^{{ }^{2}}$ Significantly different from the applied $\mathrm{P}$ treatment at $p<0.05$.

\section{Results}

Lettuce response to preplant Pfertilization. In these fields of moderate to high STP values $\left(>50 \mathrm{mg} \cdot \mathrm{kg}^{-1} \mathrm{P}_{\mathrm{bc}}\right)$ P fertilization had negligible impact on the early growth of lettuce, with no significant differences in percent canopy cover observed in any field; across trials there was $<1 \%$ difference in early-season canopy cover between the plus $\mathrm{P}$ and no $\mathrm{P}$ plots. In only one field (1) was a significant yield response to $\mathrm{P}$ fertilization observed for whole or marketable plant mass (Table 2). That field was planted in early April (cool soil temperature), and had $54 \mathrm{mg} \cdot \mathrm{kg}^{-1} \mathrm{P}_{\mathrm{bc}}$ among the lowest of the trial sites. Phosphorus fertilization increased the percent of marketable plants only in field 1; this difference was the result of undersized heads in plots without P. Field 7 had similar

HortScience Vol. 40(5) August 2005 
cultural conditions to field 1 (early-season planting, lower $\mathrm{P}_{\mathrm{bc}}$ ), and though not statistically significant, there was a trend $(p<0.15)$ toward greater plant mass with $\mathrm{P}$ fertilization.

Fields in which $\mathrm{P}_{b c}$ was substantially higher, or that were planted in warmer soil, showed no response to applied P. Excluding fields 1 and 7, plant whole and marketable mass, and percent marketable plants were essentially identical in plots with or without preplant $\mathrm{P}$ (Table 2). The mean of $15 \%$ unmarketable plants in both treatments represented a loss typical of commercial production in the Salinas Valley. Field 4 exhibited low plant vigor in both treatments, suggesting that $P$ fertility was not the growth-limiting factor. The relatively small mean plant mass in some other fields was due to high density planting for utilization in fresh-cut salad products.

Phosphorus fertilization had minimal impact on tissue $\mathrm{P}$ concentration, with variability in all measures of plant $\mathrm{P}$ status far greater among fields than between treatments within fields (Fig. 1). Current P sufficiency standards given by Ludwick (2002) are $0.40 \%$ for midseason leaf $\mathrm{P}$, and $3,000 \mu \mathrm{g} \cdot \mathrm{g}^{-1}$ for midrib $\mathrm{PO}_{4}$-P. Only the no $\mathrm{P}$ treatment in Field 10 (spring planted, $55 \mathrm{mg} \cdot \mathrm{kg}^{-1} \mathrm{P}_{\mathrm{bc}}$ ) had leaf $\mathrm{P}$ below the $0.40 \%$ threshold; there was no significant reduction in whole or marketable plant mass in these plots. However, several fields were near or below the $3,000 \mu \mathrm{g} \cdot \mathrm{g}^{-1}$ $\mathrm{PO}_{4}-\mathrm{P}$ midrib threshold, including fields with extremely high STP levels; the highest midrib value recorded in either treatment in any field was only $3,540 \mu \mathrm{g} \cdot \mathrm{g}^{-1}$. Phosphorus application also had little influence on crop Puptake.Across fields, above-ground biomass $\mathrm{P}$ of fertilized plots averaged $14 \mathrm{~kg} \cdot \mathrm{ha}^{-1}$, with the difference between the plus $\mathrm{P}$ and no $\mathrm{P}$ treatments about $0.5 \mathrm{~kg} \cdot \mathrm{ha}^{-1}$. P removal in marketable heads averaged $10 \mathrm{~kg} \cdot \mathrm{ha}^{-1}$ in fertilized plots, with no $P$ plots averaging $9.5 \mathrm{~kg} \cdot \mathrm{ha}^{-1}$.

Relationship between soil test $P$ and bioavailable $P$. The 30 soils collected in the field survey ranged from 15 to $177 \mathrm{mg} \cdot \mathrm{kg}^{-1} \mathrm{P}_{\mathrm{bc}}$, averaging $75 \mathrm{mg} \cdot \mathrm{kg}^{-1}$. The soils ranged in texture from sandy loam to clay; $\mathrm{pH}$ ranged from 6.1 to 7.9 , with only two soils below $\mathrm{pH}$ 6.5. Bicarbonate extractable $\mathrm{P}$ was highly correlated with $\mathrm{P}_{\text {ba }}(r=0.89, p<0.01)$, supporting the validity of $\mathrm{P}_{\mathrm{bc}}$ as an index of bioavailable $\mathrm{P}$ (Fig. 2). The effect of soil temperature on $\mathrm{P}$ bioavailability was strongly significant $(p<$ 0.01 ), and consistent across soils. As measured with the $\mathrm{P}_{\mathrm{ba}}$ technique, bioavailable Pincreased about $40 \%$ across soils for each $10{ }^{\circ} \mathrm{C}$ increment in soil temperature (Fig. 3). The range of 15 to $25^{\circ} \mathrm{C}$ encompasses typical seasonal soil temperatures encountered during lettuce production in the Salinas Valley.

\section{Discussion}

Prior research on the $\mathrm{P}$ requirements of lettuce reported a range of STP thresholds beyond which a yield response would not be expected (Diaz et al., 1988; McPharlin et al., 1996; Nagata et al., 1992; Prasad et al., 1988; Sanchez and El-Hout, 1995); however, these threshold values may overestimate what is likely on soils with elevated STP, such as those now commonly found in the Salinas Valley. Results of this study suggest that for iceberg and romaine lettuce, the probability of obtaining a yield response from preplant $\mathrm{P}$ application in fields with $\mathrm{P}_{\mathrm{bc}}>60 \mathrm{mg} \cdot \mathrm{kg}^{-1}$ is low. Below $60 \mathrm{mg} \cdot \mathrm{kg}^{-1} \mathrm{P}_{\mathrm{bc}}$, we found only one of four fields in which preplant $\mathrm{P}$ application significantly increased yield. Plant-available $\mathrm{P}$ appeared limited in this field, likely due to low soil temperature; soil temperature in the Salinas Valley $(15 \mathrm{~cm}$ depth) averages about $18{ }^{\circ} \mathrm{C}$ in April, compared to $24^{\circ} \mathrm{C}$ in summer (Fox and Hatfield, 1983). Other researchers have also found that lower soil temperatures can reduce plant-available soil $\mathrm{P}$ to growthlimiting growth levels (McCallister etal., 1997; Prasad et al., 1988; Singh and Jones, 1977); higher STP was advocated for maximum yield during cooler seasons. Lower soil temperature in the root zone decreases the conversion of organic P to inorganic orthophosphate; the majority of plant-absorbed $\mathrm{P}$ is taken up by lettuce as inorganic orthophosphate (Broadley et al., 2002).

Using a membrane incubation purported to measure bioavailable $P$, we found a substantial decline in plant-available $\mathrm{P}$ with reduced soil temperature (about $40 \%$ for each $10{ }^{\circ} \mathrm{C}$ reduction); this magnitude of effect was somewhat smaller than that of Singh and Jones (1977). Our data suggested that the agronomic threshold $\mathrm{P}_{\mathrm{bc}}$ for early-season lettuce production would need to be about $40 \%$ higher than for summer conditions. In these field trials threshold $\mathrm{P}_{\mathrm{bc}}$ for early season production was in the range of 50 to $60 \mathrm{mg} \cdot \mathrm{kg}^{-1}$. Because the likelihood of a yield response was not great even within this range
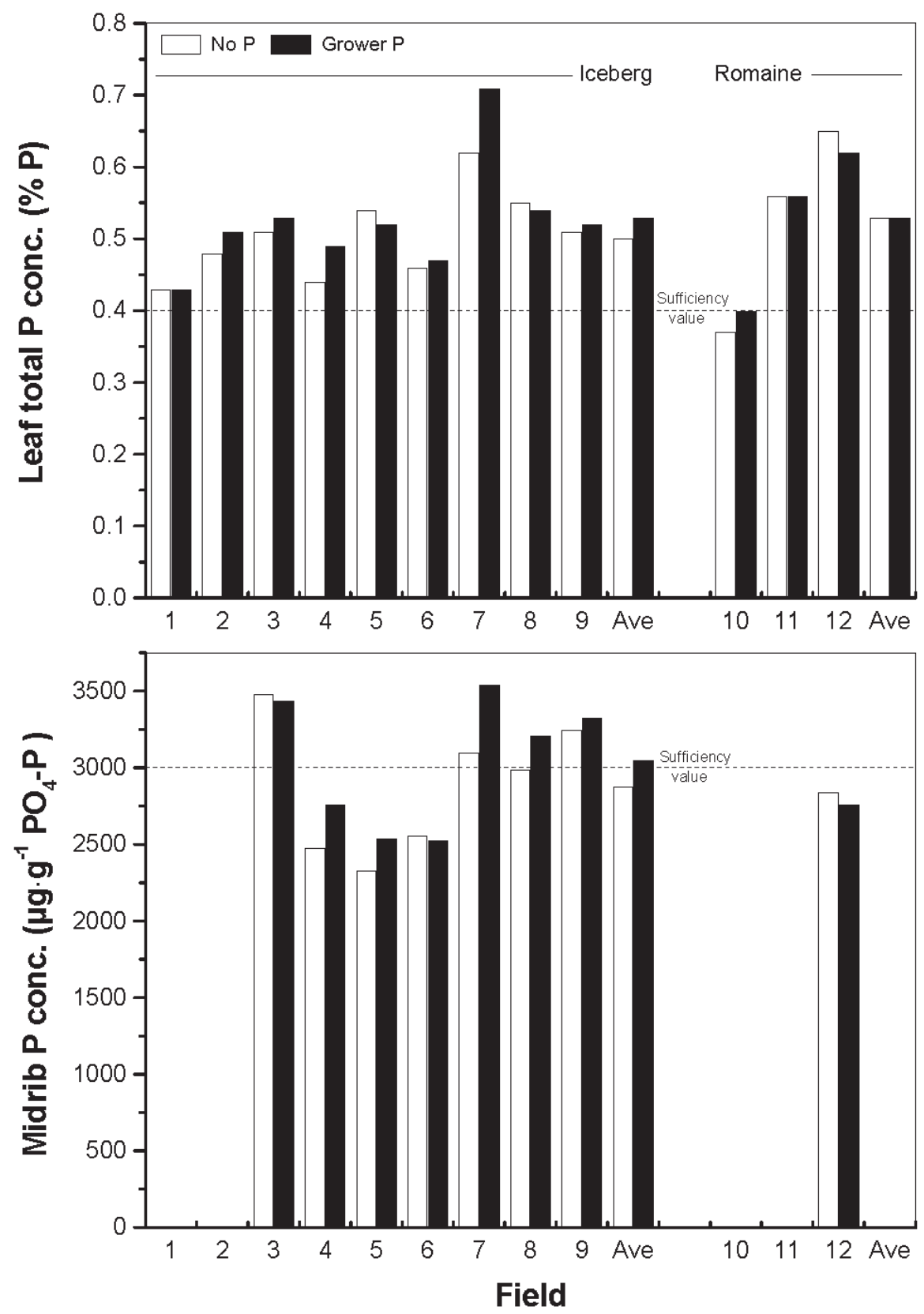

Fig. 1. Effect of P fertilization on lettuce tissue P concentration at heading; sufficiency values from Ludwick (2002). 
(only one of three early-season fields with $\mathrm{P}_{\mathrm{bc}}$ lower than $60 \mathrm{mg} \cdot \mathrm{kg}^{-1}$ showed a significant yield response to preplant $\mathrm{P}$ ), only a low rate of $\mathrm{P}$ application appeared justified. The implication of the $\mathrm{P}_{\mathrm{ba}}$ data was that under summer conditions threshold $\mathrm{P}_{\mathrm{bc}}$ would be about 35 to 40 $\mathrm{mg} \cdot \mathrm{kg}^{-1}$, more in agreement with the thresholds suggested by Ludwick (2002) and Prasad et al. (1998). That hypothesis was not confirmed in the present study because no fields in this STP range were included; indeed, such fields are now uncommon in the Salinas Valley.

These field trials also suggested that the current $3000 \mu \mathrm{g} \cdot \mathrm{g}^{-1}$ sufficiency level for midrib
$\mathrm{PO}_{4}-\mathrm{P}$ (Ludwick, 2002) may overestimate the actual crop sufficiency threshold for lettuce grown in the Salinas Valley; a threshold of no higher than $2,500 \mu \mathrm{g} \cdot \mathrm{g}^{-1} \mathrm{PO}_{4}-\mathrm{P}$ appeared appropriate. Given the comparatively short growth cycle of lettuce (about $60 \mathrm{~d}$ in Salinas summer conditions) and the difficulty inherent in making an effective in-season Papplication, midrib analysis has limited value as a management tool for the current crop. The greater value of tissue $\mathrm{P}$ analysis may be as a planning tool for succeeding crops.

The tendency of growers to over-fertilize was evident by $\mathrm{P}$ application in 9 of the 11

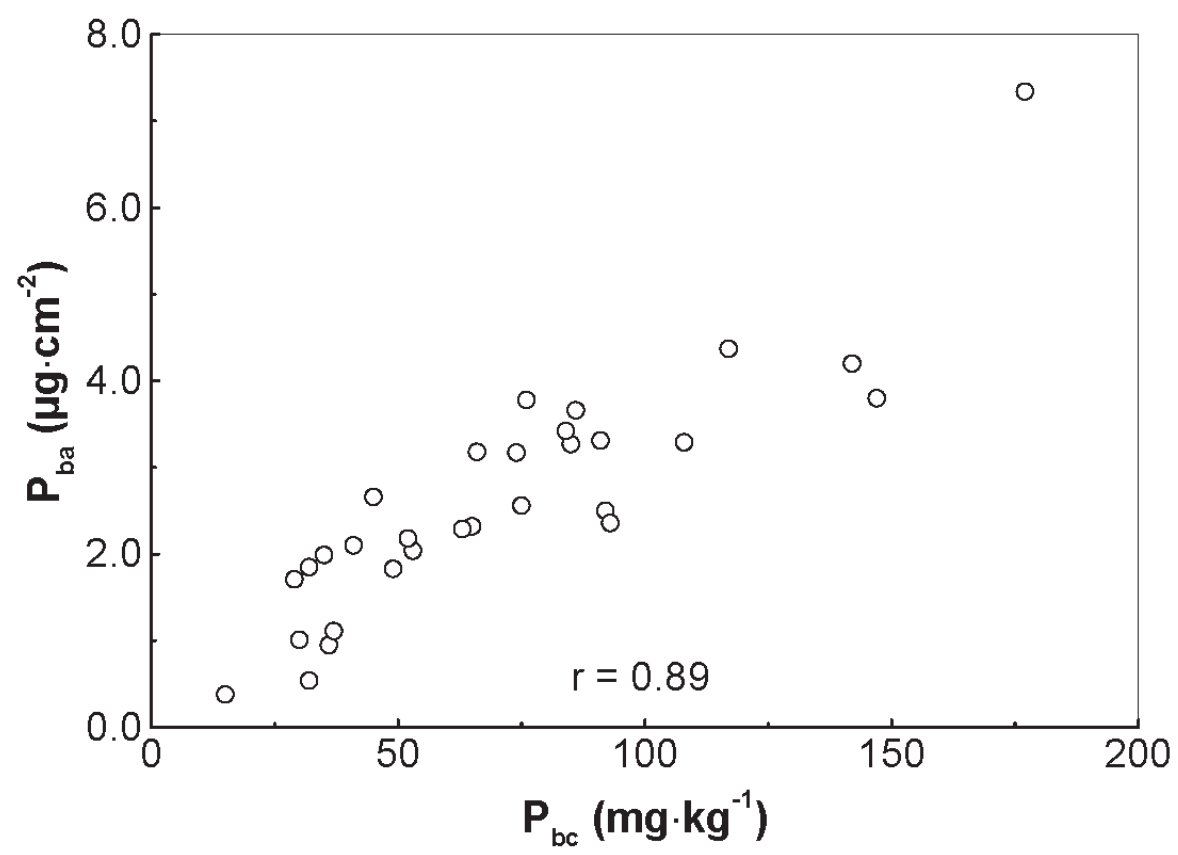

Fig. 2. Relationship between bicarbonate-extractable $\mathrm{P}\left(\mathrm{P}_{\mathrm{bc}}\right)$ and bioavailable $\mathrm{P}\left(\mathrm{P}_{\mathrm{ba}}\right.$, anion resin technique at $20^{\circ} \mathrm{C}$ ).

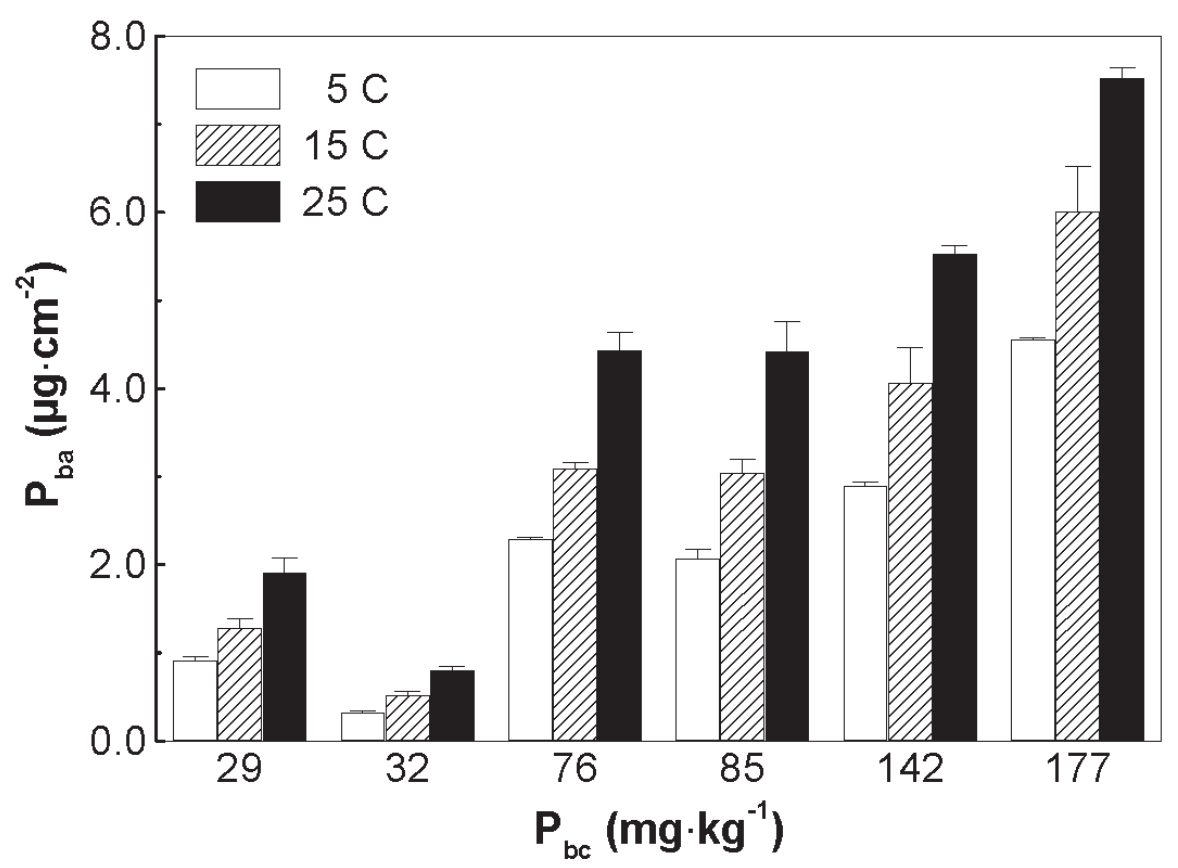

Fig. 3. Effect of temperature on soil $\mathrm{P}$ bioavailability $\left(\mathrm{P}_{\mathrm{ba}}\right.$, anion resin technique); bars indicate standard error.

nonresponsive fields. Considering that substantially more $\mathrm{P}$ is typically applied than is removed in the harvested product, $\mathrm{P}$ fertilization practices over many years have contributed to the elevated STP values now common in the Salinas Valley. Wijk et al. (2000) also found a large disparity between applied fertilizer $P$ and the percent removed from fields in the marketable lettuce heads; over a range of low to high soil $\mathrm{P}$ levels, average $\mathrm{P}$ removal was about $3 \%$ of applied $\mathrm{P}\left(53 \mathrm{~kg} \cdot \mathrm{ha}^{-1}\right)$. Although our cooperating growers applied less P (33 $\mathrm{kg} \cdot \mathrm{ha}^{-1} \mathrm{P}$ on average), the effective fertilizer recovery was very poor; crop biomass $\mathrm{P}$ was increased only $0.5 \mathrm{~kg} \cdot \mathrm{ha}^{-1}$ by P fertilization, an uptake efficiency of $<2 \%$. Continued fertilization of high $P$ soils in excess of crop removal only increases the potential for significant $\mathrm{P}$ loss to the environment (Pote et al., 1996); runoff from such fields can carry a substantial amount of soluble and sediment-bound $\mathrm{P}$ (Johnstone and Hartz, 2004; Pote et al., 1996; Sharpley, 1995). Given the modest P removal rate of lettuce found in this study, it will take a number of crop cycles of little or no P application to significantly reduce STP levels in the Salinas Valley.

Continued P fertilization in high STP fields reflected the perception that traditional agronomic tests such as $\mathrm{P}_{\mathrm{bc}}$ relate poorly to plant-available P (bioavailable P). We found $\mathrm{P}_{\mathrm{bc}}$ to be strongly correlated with $\mathrm{P}_{\mathrm{ba}}$. Burt et al. (2002) also reported a high correlation between these measures, but cautioned against predicting bioavailable $\mathrm{P}$ based exclusively on $\mathrm{P}_{\mathrm{bc}}$. Given that the $\mathrm{P}_{\mathrm{ba}}$ technique is a complicated laboratory procedure, $\mathrm{P}_{b c}$ remains the most practical analytical soil test technique. However, our data suggested that consideration of soil temperature would improve the prediction of bioavailable $\mathrm{P}$.

\section{Literature Cited}

Broadley, M.R., A. Burns, and I.G. Burns. 2002. Relationships between phosphorus forms and plant growth. J. Plant Nutr. 25:1075-1088.

Burt, R., M.D. Mays, E.C. Benham, and M.A. Wilson. 2002. Phosphorus characterization and correlation with properties of selected benchmark soils of the United States. Commun. Soil Sci. Anal. 33:117-141.

Cooperband, L.R. and T.J. Logan. 1994. Measuring in-situ changes in labile soil phosphorus with anion-exchange membranes. Soil Sci. Soc.Amer. J. 58:105-114.

Diaz, O.A., E.A. Hanlon, G.J. Hochmuth, and J.M White. 1988. Phosphorus and potassium nutrition of lettuce on a Florida muck. Soil Crop Sci. Soc. Florida Proc. 47:36-41.

Fox, R.L. 1981. External phosphorus requirements of crops, p. 223-239. In: R.H. Dowdy et al. (eds.). Chemistry in the soil environment. Amer. Soc. Agron. Special Publ. 40.

Fox, J.A. and J.L. Hatfield. 1983. Soil temperatures in California. Univ. Calif. Bul. 1908.

Franson, M.A.H. (ed.). 1998. Flow injection analysis for orthophosphate, p 4:149-150. In: Standard methods for the examination of water and wastewater. 20th ed. Amer. Public Health Assn., Wash., DC.

Gee, G.W. and J.W. Bauder. 1982. Particle-size analysis, p. 383-411. In: A. Klute (ed.). Methods of soil analysis: Part 1. Physical and mineralogi- 
cal methods. ASA Monogr. 9.

Greenwood, D.J., T.J. Cleaver, M.K. Turner, J. Hunt, K.B. Niendorf, and S.M.HLoquens. 1980. Comparison of the effects of phosphate fertilizer on the yield, phosphate content and quality of 22 different vegetable and agricultural crops. J. Agr. Sci. 95:457-469.

Johnstone, P.R. and T.K. Hartz. 2004. Soil phosphorus and environmental risk. HortScience 39:797 (abstr.).

Kumar, V., R.J. Gilkes, and M.D.A. Bolland. 1992.A comparison of seven soil P tests for plant species with different external $P$ requirements grown on soils containing rock phosphate residues. Fert. Res. 33:35-45.

Ludwick, A.E. (ed.). 2002. Western fertilizer handbook. 9th ed. Interstate Publ., Danville, Ill.

Magdoff, F.R., C. Hryshko, W.E. Jokela, R.P. Durieux and Y. Bu. 1999. Comparison of phosphorus soil test extractants for plant availability and environmental assessment. Soil Sci. Soc. Amer. J. 63:999-1006.

McCallister, D.L., L.A. Jawson, and M.D. Jawson. 1997. Soil temperature and fumigation effects on plant phosphorus uptake and related microbial properties. J. Plant Nutr. 20:485-497.

McDowell, R.W. and A.N. Sharpley. 2001.Approximating phosphorus release from soils to surface runoff and subsurface drainage. J. Environ. Qual. 30:508-520.
McPharlin, I.R., R.C. Jeffery, and D.H. Pitman. 1996. Phosphorus requirements of winter-planted lettuce (Lactuca sativa L.) on a Karrakatta sand and the residual value of phosphate as determined by soil test. Austral. J. Expt. Agr. 36:897-903.

Menon, R.G., S.H. Chien, and L.L. Hamond. 1990. Development and evaluation of the $\mathrm{P}_{i}$ soil test for plant-available phosphorus. Comm. Soil. Sci. Plant Anal. 21:1131-1150.

Meyer, G.A. and P.N. Keliher. 1992. An overview of analysis by inductively coupled plasma-atomic emission spectrometry, p. 473-505. In: A Montaser and D.W. Golightly (eds.). Inductively coupled plasmas in analytical atomic spectrometry. VCH Publ., New York.

Nagata, R.T., C.A. Sanchez, and F.J. Coale. 1992. Crisphead lettuce cultivar response to fertilizer phosphorus. J. Amer. Soc. Hort. Sci. 117:721-724.

Olsen, S.R. and L.E. Sommers. 1982. Phosphorus, p. 403-430. In: A.L. Page et al. (eds.). Methods of soil analysis: Part 2. Chemical and microbiological properties. ASA Monogr. 9.

Pote, D.H., T.C. Daniel, A.N. Sharpley, P.A. Moore, D.R. Edwards, and D.J. Nichols. 1996. Relating extractable soil phosphorus to phosphorus losses in runoff. Soil Sci. Soc. Amer. J. 60:855-859.

Prasad, M., T.M. Spiers, and I.C. Ravenwood. 1988. Target phosphorus soil test values for vegetables. N.Z. J. Expt. Agr. 16:83-90.
Prokopy, W.R. 1995. Phosphorus in acetic acid extracts. QuikChem Method 12-115-01-1-C. Lachat Instr., Milwaukee, Wis.

Reisenauer, H.M. 1983. Soil and plant tissue testing in California. Univ. Calif. Bul. 1879.

Sah, R.N. and R.O. Miller. 1992. Spontaneous reaction for acid dissolution of biological tissues in closed vessels. Anal. Chem. 64:230-233.

Sanchez, C.A. and N.M. El-Hout. 1995. Response of diverse lettuce types to fertilizer phosphorus. HortScience 30:528-531.

Sharpley, A.N. 1995. Dependence of runoff phosphorus on extractable soil phosphorus. J. Environ. Qual. 24:920-926.

Sims, J.T. 1998. Phosphorus soil testing: innovations for water quality protection. Comm. Soil Sci. Plant Anal. 29:1471-1489.

Sims, J.T., A.C. Edwards, O.F. Schoumans, and R.R. Simard.2000. Integrating soil phosphorus testing into environmentally based agricultural management practices. J. Environ. Qual. 29:60-71.

Singh, B.B. and J.P. Jones. 1977. Phosphorus sorption isotherm for evaluating phosphorus requirements of lettuce at five temperature regimes. Plant Soil 46:31-44.

Wijk, C. van., J. Neuvel, J. Alblas, and H. Titulaer. 2000. Yield and quality of early head lettuce in relation to phosphate fertilization and phosphate status of the soil. Acta Hort. 511:81-88. 